\title{
Facies and Reservoir Characteristics of the Ngrayong Sandstone in the Rembang Area, Northeast Java (Indonesia)
}

\author{
San Yee Khaing1 ${ }^{*}$, Sugeng Sapto Surjono², Jarot Setyowiyoto ${ }^{2}$, Yuichi Sugai ${ }^{1}$ \\ ${ }^{1}$ Department of Earth Resource Engineering, Faculty of Engineering, Kyushu University, Fukuoka, Japan \\ ${ }^{2}$ Geological Engineering Department, Faculty of Engineering, Gadjah Mada University, Yogyakarta, Indonesia \\ Email: ^poeoo.34@gmail.com
}

How to cite this paper: Khaing, S.Y., Surjono, S.S., Setyowiyoto, J. and Sugai, Y. (2017) Facies and Reservoir Characteristics of the Ngrayong Sandstone in the Rembang Area, Northeast Java (Indonesia). Open Journal of Geology, 7, 608-620. https://doi.org/10.4236/ojg.2017.75042

Received: March 17, 2017

Accepted: May 8, 2017

Published: May 11, 2017

Copyright ( 2017 by authors and Scientific Research Publishing Inc. This work is licensed under the Creative Commons Attribution International License (CC BY 4.0). http://creativecommons.org/licenses/by/4.0/

\section{Open Access}

\begin{abstract}
The Rembang area is a well-known prospective region for oil and gas exploration in Northeast Java, Indonesia. In this study, the reservoir characteristics of the Ngrayong Sandstone were investigated based on outcrops in the Rembang area. Petrological, mineralogical, petrophysical and sedimentological facies analyses were conducted. These sandstones are grain- and matrix-supported, and composed of very fine to medium, sub-angular to poorly-rounded, moderately- to very well-sorted sand grains. These sandstones are mainly composed of quartz, orthoclase, plagioclase, and micas with minor amounts of clay minerals, and therefore are predominantly classified as sub-lithic arenite and sub-felds pathicarenite. Petrographic observations and grain size data indicate that these sandstones are texturally quite mature, based on their good -sorting and the occurrence of minor amounts of matrix clays. Common clays in the samples include illite, smectite, kaolinite, and gibbsite. The porosity of the Ngrayong sandstones ranges from $25.97 \%$ to $40.21 \%$, and the permeability ranges from 94.6 to 3385 millidarcies. Thus, these sandstones exhibit well to excellent reservoir qualities. Eight lithofacies were identified from five measured stratigraphic sections, and are dominated by foreshore and tide-dominated shoreface facies. The Ngrayong sequence shows a single transgressiveregressive cycle. Cross-bedded sandstone and massive sandstone are identified as the most promising potential reservoir facies based on their characteristics in outcrops, their lateral and vertical distributions, their sedimentological characteristics and their petrophysical properties.
\end{abstract}

\section{Keywords}

Reservoir Characteristics, Facies Analysis, Permeability, Hydrocarbon Exploration 


\section{Introduction}

The Northeast Java Basin is a Tertiary sedimentary basin in Indonesia that covers an area of approximately $50 \mathrm{~km}^{2}$ in the eastern part of Central Java, East Java, Madura and the areas adjoining the East Java Sea and Madura Straits. It consists of a relatively stable northern platform and a series of deep basins to the south. The Northeast Java Basin has a long history of petroleum production. Early hydrocarbon exploration was mainly conducted in the onshore portion of the ba$\sin$.

The Ngrayong Formation is one of the most prolific reservoirs in the Northeast Java Basin; hydrocarbon has been produced from its reservoir since the 19th century [1]. A cumulative 150 million barrels of oil have been extracted from the Ngrayong Sandstone, which represents about $75 \%$ of the total hydrocarbon production of the basin [2]. The Ngrayong Sandstone exhibits a complete regressive-transgressive sequence that comprises coarse-grained sandy clastics with thin layers of limestones at the top of the formation. The Ngrayong Sandstone is regarded as a clean, quartzose, fine- to medium-grained, well-sorted, and commonly cross-bedded sandstone unit. This sandstone has been interpreted as deposited in various sedimentary environments, such as inner and outer neritic and bathyal settings, and was influenced by a wide variety of sedimentary processes. Consequently, interpretation of the depositional environment of the Ngrayong Sandstone is still under debate. The observed complex variation in sedimentary facies has been attributed to the complexity of the depositional environments. Therefore, the reservoir varies both qualitatively and quantitatively as the sandstone varies geographically throughout the basin (Figure 1).

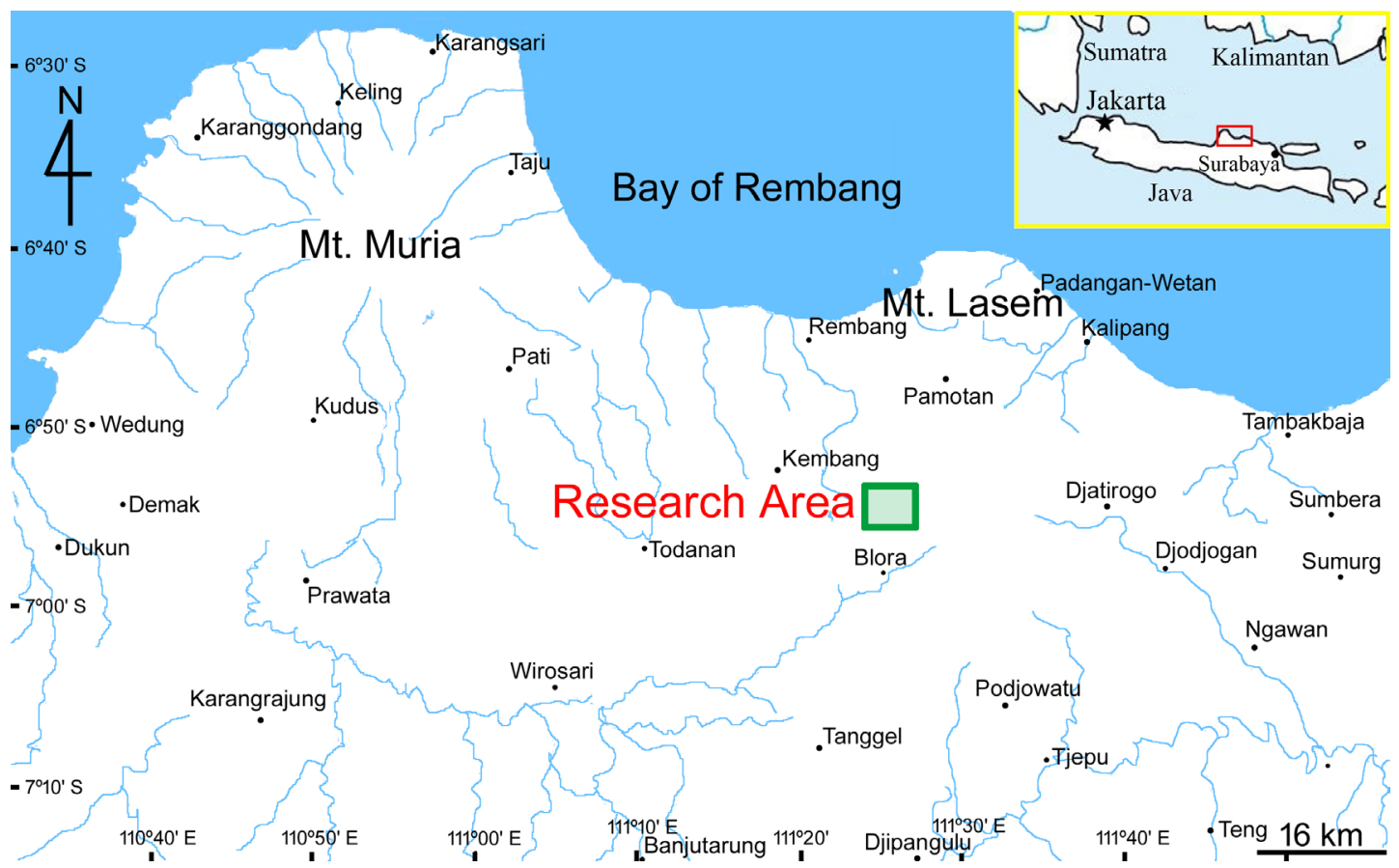

Figure 1. Location map of the Rembang area, Northeast Java, Indonesia. 
The Rembang area is a prospective region for oil and gas in the Northeast Java Basin. The generative reservoir rock, the Ngrayong Sandstone, crops out in several localities in this area. Occurrences of oil and gas seepage observed in this sandstone unit represent a potentially viable petroleum system in the subsurface; therefore, this area may be promising for future exploration. For such future exploration to be successful, a more precise understanding of the characteristics and geological conditions of the Ngrayong Sandstone is required. This study was therefore conducted to investigate the quality of the siliciclastic reservoir rock, especially the Ngrayong Sandstone, based on observations of sedimentary facies distribution, variation in depositional environments, and internal characters. This detailed research was conducted to characterize the reservoir geology and petrophysical properties of the Ngrayong Sandstone in the Rembang area of Northeast Java, Indonesia.

\section{Research Methods}

This research is based on field investigations involving facies analysis of five measured stratigraphic sections and supported by petrographic study, granulometric analysis, X-ray diffraction (XRD) analysis and petrophysical analysis. Stratigraphic sections were measured at five different locations along the road between Blora and Rembang. Attributes of the rock strata and geological structures, such as strike and dip, joints, folding and faults, were measured with a Brunton compass. The lithology, texture, sedimentary structures, fossil content and tectonic deformation were observed and recorded during measurements.

Petrographic study was performed to determine the composition, texture and fabric of the sandstone as well as the characteristic of the pores spaces. Fifteen samples were prepared for this petrographic analysis. All of the prepared thinsections were impregnated with blue epoxy to expose the voids or pore spaces in the samples. The proportions of the constituent mineral grains were estimated visually to determine the mineral composition of the sandstone.

The minerals and specific types of clay present in the sandstone were identified using XRD. This analysis included both powdered bulk rock and clay fraction analyses. Three samples were prepared for XRD analyses. Air-drying and ethylene glycolation were employed to treat the clay fraction. To confirm the presence of smectite clay, the swelling of the diffraction peak d-value was checked with the ethylene glycol (EG)-treated samples.

To investigate the textural maturity of the sandstones, granulometric analysis of fifteen samples was performed to determine the quantitative distribution of grain sizes and the sorting of the grains. The classification scheme and terminology of Pettijohn et al. [3] was used, including class intervals for grading. Percentile value or phi values (such as Ø5, Ø16, Ø25, Ø50, Ø75, Ø84 and Ø95), applied in the calculations, were deduced from a binary plot of the cumulative weight percent versus the phi value. Parameters such as the geomeric graphic mean, graphic standard deviation, skewness, and kurtosis were applied for defining grain size, sorting, and skewness. Statistical analyses were carried out to 
quantify the grain size, sorting, roundness and skewness of the analyzed sandstone using these percentile values and following the standard formulas.

The petrophysical analysis included determining the porosity and permeability to evaluate the quality of the Ngrayong Sandstone as a reservoir. Nine outcrop samples of the Ngrayong sandstone were selected and analyzed for porosity and permeability.

Petrographic microscopy, XRD analysis, and granulometric analysis were performed at the laboratory of the Geological Engineering Department, Faculty of Engineering, Gadjah Mada University, Yogyakarta (Indonesia). Porosity and permeability were measured at the laboratories of the Petroleum Engineering Department, Universitas Pembangunan Nasional (Veteran), Yogyakarta (Indonesia) and at the Laboratory of National Oil Institute Legimas (Lembaga Minyak Dan Gas Bumi), Jakarta (Indonesia).

\section{Result and Discussion}

\subsection{Petrographic Analysis}

The modal compositions of the sandstone samples were determined petrographically. The sandstones were classified based on modal composition using the triangular quartz-feldspar-lithics (QFL) diagram of Pettijohn [4] (Figure 2(a), Figure 2(b)). The samples were classified as sub-lithic arenite, sub-felds pathicarenite, and lithic greywacke (Figure 3(a), Figure 3(b)). The majority of the sandstones are arenite in composition (Figure 4(a), Figure 4(b)). These sandstones are mainly composed of quartz, orthoclase, plagioclase, muscovite and biotite with minor pyroxene, hornblende and magnetite. They are mediumto very fine-grained and both matrix- and grain-supported, with grains that are angular to poorly-rounded and moderately to very well-sorted (Figure 5(a), Figure 5(b)). However, most of these sandstones are fine-grained, very wellsorted and grain-supported. The porosities of the sandstones were estimated from petrographic study, and range from $5 \%$ to $30 \%$.

\subsection{X-Ray Diffraction Analysis}

The results of the XRD analysis indicate that quartz and orthoclase are the main

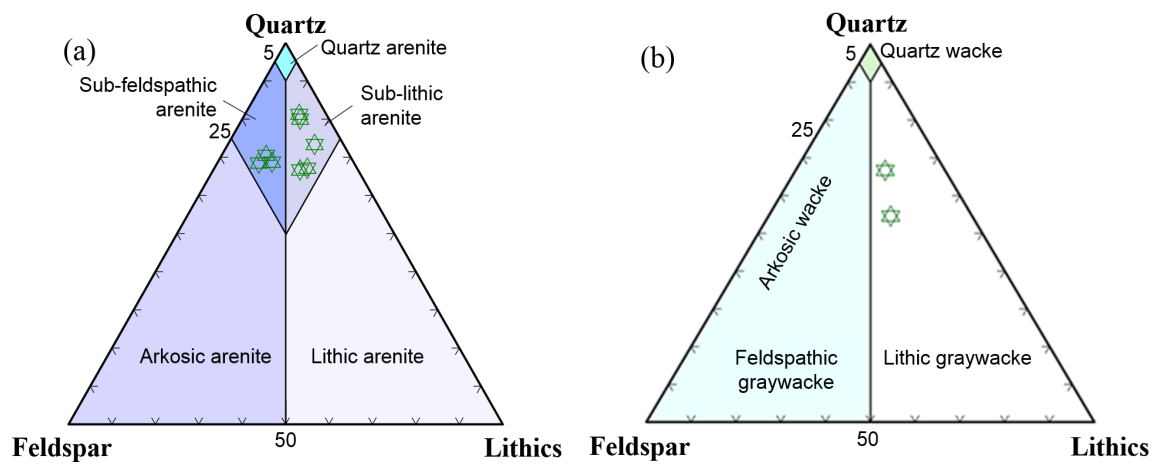

Figure 2. QFL triangular classification plot (Pettijohn, 1975) of different sandstones from Rembang area. 

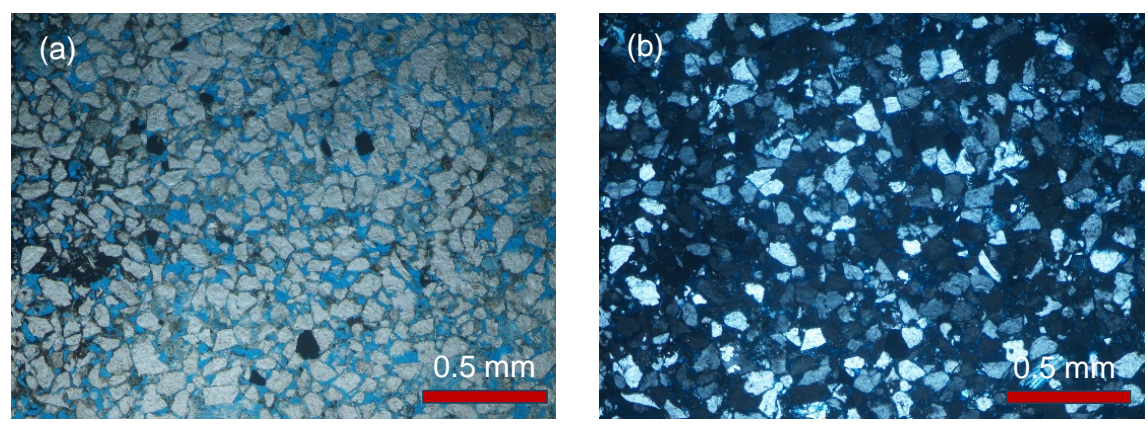

Figure 3. Very well-sorted, grain-supported, fine-grained nature of Ngrayong sandstone (Sub-felds parthicarenite) under (a) Plane polarized light, and (b) Cross polarized light.
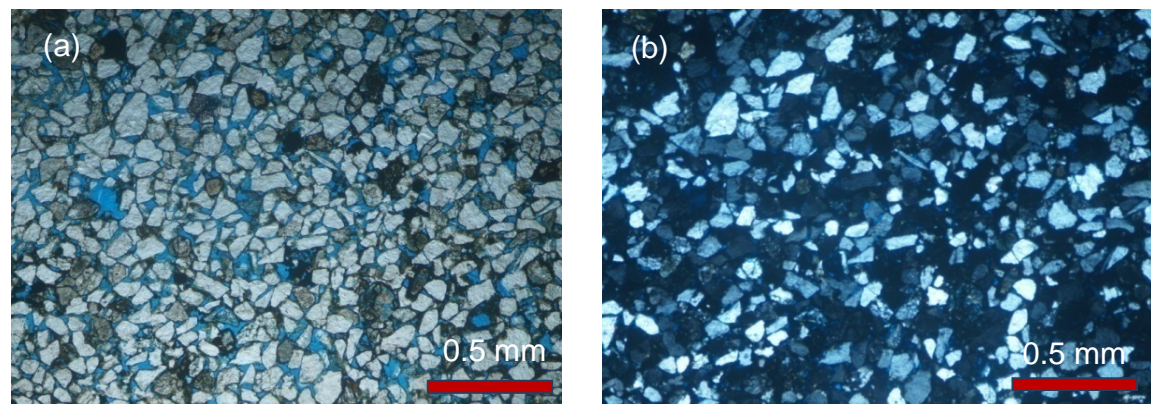

Figure 4. Very well-sorted, grain-supported, fine-grained nature of Ngrayong sandstone (Sub-lithic arenite) under (a) Plane polarized light and (b) Cross polarized light.
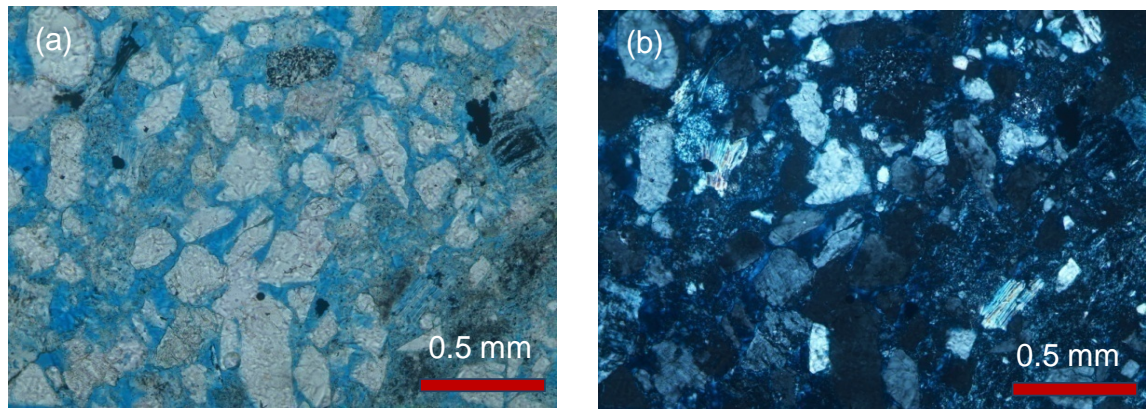

Figure 5. Moderately-sorted, matrix-supported, medium-grained nature of Ngrayong sandstone (Lithic-greywacke) under (a) Plane polarized light and (b) Cross polarized light.

constituents of these sandstones (Figure 6(a)).The clay minerals identified via XRD analysis includeillite, kaolinite, smectite and gibbsite (Figures 6(b)-6(d)).

Quartz is identified based on its diffraction peaks at 4.26, 3.34, 2.46, 2.28, 2.23, $2.12,1.97,1.81,1.67,1.54$ and $1.45 \AA$, whereas orthoclase feldspar is indicated by its diffraction peaks at 7.22, 6.48, 3.76, 3.46, 3.23, 2.98, 2.88, 2.76, 2.54, and $2.15 \AA$ (Figure 6(a)). Illite shows basal spacing of diffraction peaks at $10.04-10.15$, and 5.0 - $5.03 \AA$, and these peaks do not change in EG-treated samples (Figure 6(b), Figure 6(c)). Kaolinite shows d-spacing at 7.18 - 7.22, $4.24-4.27,3.56$ and 3.33 $3.34 \AA$, and these diffraction peaks do not change in EG-treated samples (Figures 6(b)-6(d)). Smectite shows diffraction peaks at $15.38-16.1$ and $4.98 \AA$ in the air -dried clay fraction. The existence of smectite was confirmed by a shift 

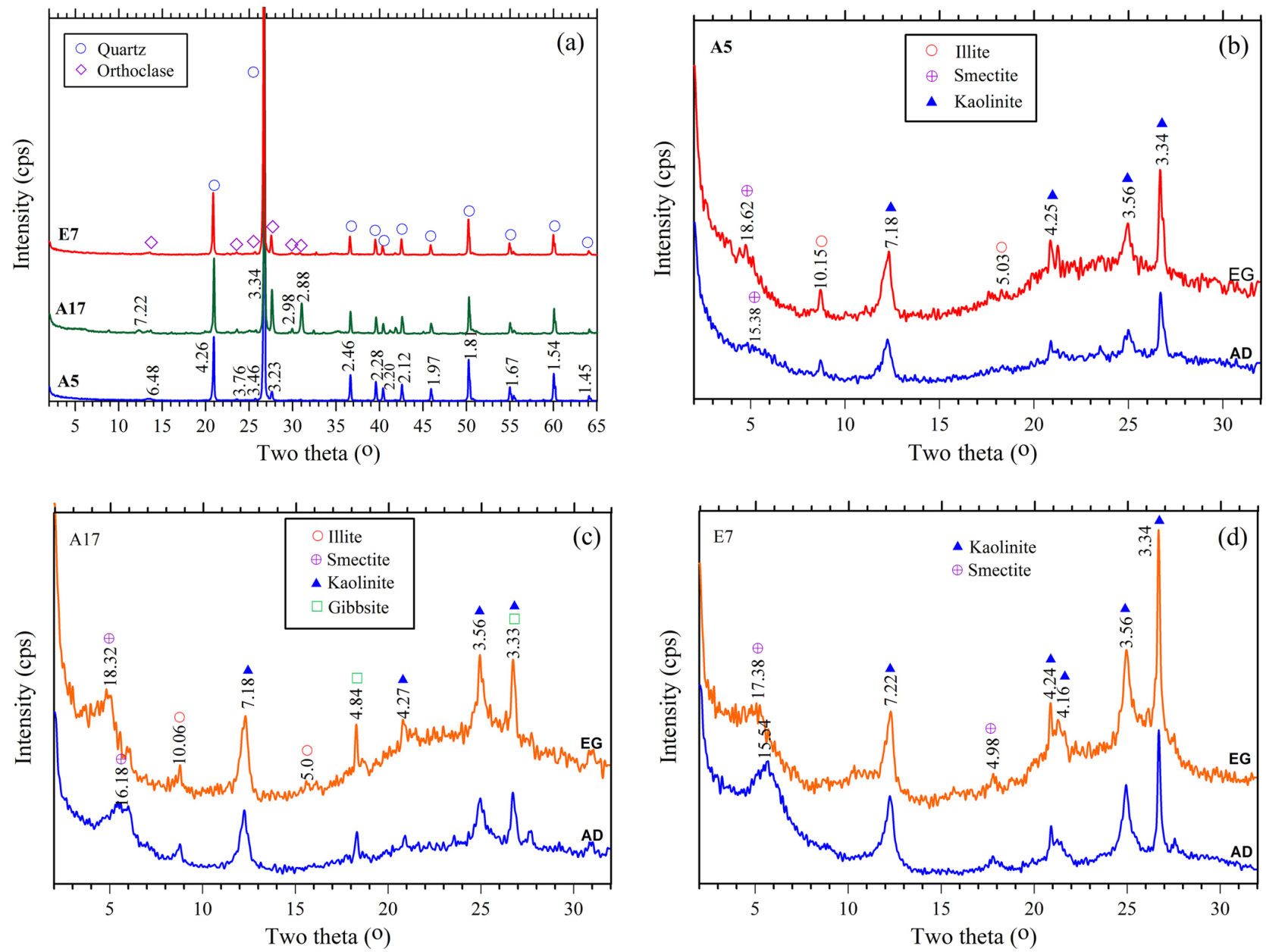

Figure 6. X-ray diffractograms of Ngrayong sandstones (a) random mount samples and (b)-(d) clay fraction samples; AD-airdried clay fraction; EG-Ethylene glycolated clay fraction.

of its first diffraction peak d-value from $\sim 15 \AA$ in the air-dried samples to $\sim 17 \AA$ after EG treatment (Figures 6(b)-6(d)). Gibbsite shows diffraction peaks at 4.84 and $3.33 \AA$ in the samples (Figure 6(c)).

\subsection{Sieve Analysis}

Based on the result of the sieve analysis, the Ngrayong sandstones are very fineto medium-grained (phi values: 1.67 to 3.35 ), moderately- to well-sorted (standard deviation: 0.19 to 0.57 ), strongly fine-skewed to strongly coarse-skewed (skewness values: 4.82 to -5.97 ), and very platykurtic to very leptokurtic (kurtosis values: 0.36 to 2.41 ). The granulometric data indicate that these sandstones are texturally quite mature. The result of the granulometric analysis is shown in (Table 1).

\subsection{Petrophysical Analysis}

Petrophysical analysis includes determining porosity and permeability. The results of petrophysical analysis of these sandstones are shown in (Table 2). Adopting the classification scheme of Koesoemadinata [5], the porosity of the 
Table 1. Result of granulomatric analysis of Ngrayong Sandstones.

\begin{tabular}{cccccccccc}
\hline Sp. ID & Mean & Size Class & $\begin{array}{c}\text { Standard } \\
\text { Deviation }\end{array}$ & Sorting Class & $\begin{array}{c}\text { Sorting } \\
\text { Skewness }\end{array}$ & Class & \multicolumn{2}{c}{$\begin{array}{c}\text { Sorting } \\
\text { Kurtosis }\end{array}$} & Class \\
\hline A2 & 2.07 & Fine sand & 0.39 & Well sorted & 0.25 & Fine-skewed & 1.26 & Leptokurtic \\
A5 & 1.67 & Medium sand & 0.57 & Moderately sorted & -2.53 & Strongly coarse-skewed & 2.41 & Very leptokurtic \\
B6 & 2.57 & Fine sand & 0.21 & Very well sorted & 3.75 & Strongly fine-skewed & 0.53 & Very platykurtic \\
C2 & 2.53 & Fine sand & 0.22 & Very well sorted & 1.09 & Strongly fine-skewed & 0.82 & Platykurtic \\
C9 & 2.76 & Fine sand & 0.34 & Very well sorted & 2.25 & Strongly fine-skewed & 0.67 & Platykurtic \\
D3 & 2.79 & Fine sand & 0.42 & Well sorted & -0.74 & Strongly coarse-skewed & 0.99 & Mesokurtic \\
D8 & 3.22 & Very fine sand & 0.51 & Moderately sorted & -3.97 & Strongly coarse-skewed & 1.93 & Very leptokurtic \\
E6 & 2.53 & Fine sand & 0.19 & Very well sorted & 4.82 & Strongly fine-skewed & 0.36 & Very platykurtic \\
E7 & 2.73 & Fine sand & 0.34 & Very well sorted & 0.59 & Strongly fine-skewed & 0.84 & Platykurtic \\
\hline
\end{tabular}

Table 2. Summary result of petrophysics analysis of different facies of Ngrayong Sandstones.

\begin{tabular}{cccccc}
\hline Sample ID & Facies & Porosity (\%) & Quality & Permeability (mD) & Quality \\
\hline A2 & Facies F & 30.3 & Excellent & 237.9 & Excellent \\
A5 & Facies E & 40.21 & Excellent & 2562 & Excellent \\
B6 & Facies D & 30.54 & Excellent & 274.0 & Excellent \\
C2 & Facies E & 25.97 & Excellent & 113.0 & Excellent \\
C9 & Facies A & 36.39 & Excellent & 3385 & 2104 \\
D3 & Facies G & 35.2 & Excellent & 94.64 & Excellent \\
D8 & Facies E & 27.16 & Excellent & 330.5 & Good \\
E6 & Facies D & 30.7 & Excellent & 2836 & Excellent \\
E7 & Facies A & 34.51 & Excellent & Excellent \\
\hline
\end{tabular}

analyzed sandstones is excellent in quality, and the permeability ranges from good to excellent in quality. The higher percentage of porosities in the sandstones of different facies would be probably due to the clean nature (matrix poor and loosely cemented) of the sandstones. Higher porosities and permeabilities were also probably favored by the outcrop nature of the sandstones which experienced extensive weathering. This would lead to the secondary porosity by the dissolution of the clay particles or matrix within the sandstone.

\subsection{Stratigraphic Sections and Lithofacies}

Eight lithofacies were identified from five measured stratigraphic sections (Figure 7, Figure 8) based on the characteristics of the sedimentary units, such as their lithology, grain size, color, thickness, sedimentary structures, and biogenic content [6], combined with the results of laboratory analyses such as petrographic microscopy and granulometric analysis. The identified lithofacies are a crossbedded sandstone facies (Facies A), a carbonaceous mudstone facies (Facies B), a laminated shale facies (Facies C), a thin-bedded sandstone facies (Facies D), a 


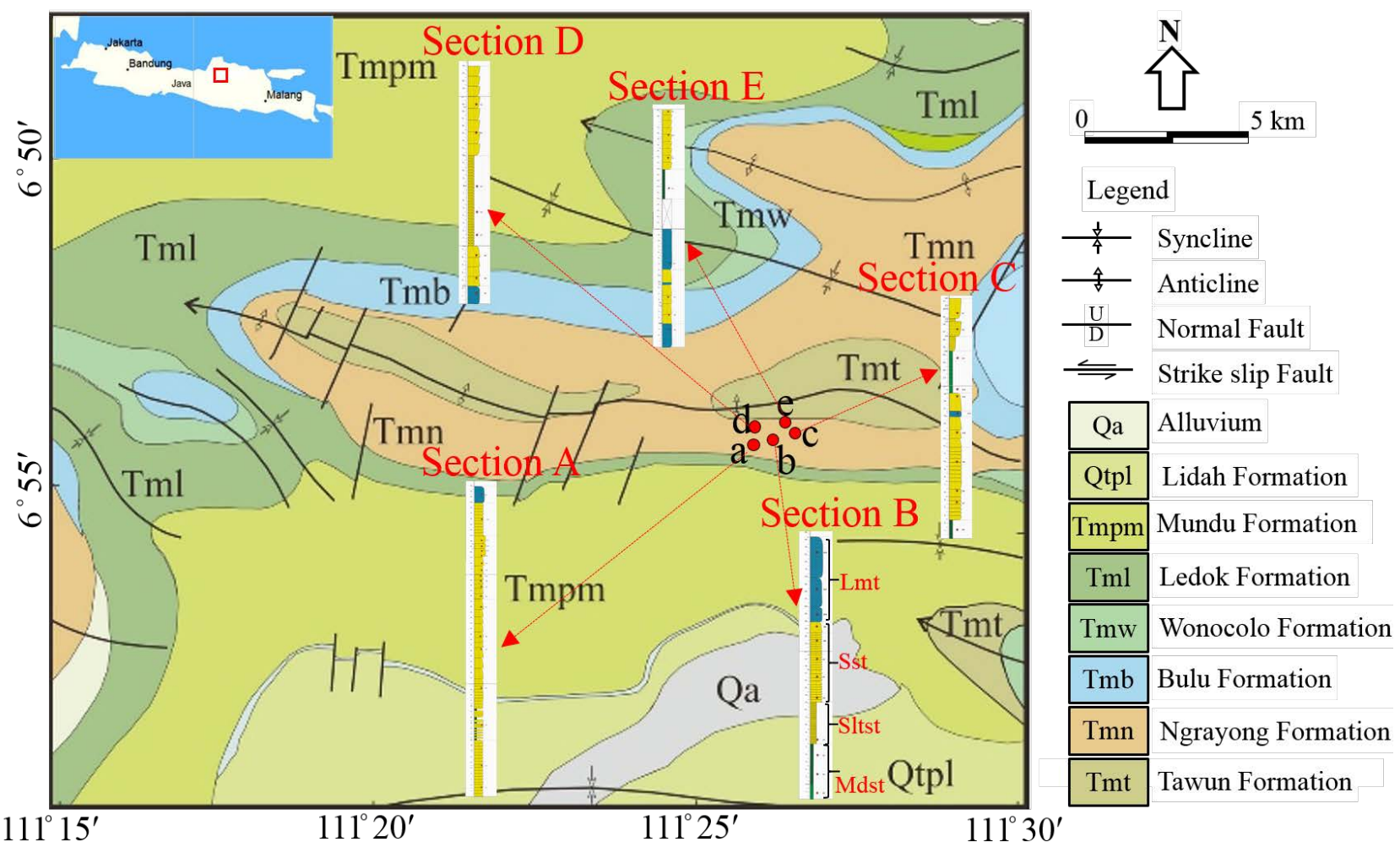

Figure 7. Regional geological map of Rembang area, Northeast Java (Indonesia) showing the location offive measured stratigraphic sections (Kadar and Sudijono). Lst-limestone, Sst-sandstone, Sltst-siltstone, Mdst-mudstone [7].

massive sandstone facies (Facies E), a bioturbated sandstone facies (Facies F), a fossiliferous sandstone facies (Facies G), and a bioclastic limestone facies (Facies $\mathrm{H})$.

The cross-bedded sandstone facies (Facies A) is dominated by sand-sized grains. In outcrop, these sandstones are whitish, yellowish and reddish brown in color, very fine- to medium-grained, and thick-bedded to massive. Sandstones in these intervals are moderately to very well-sorted, sub-angular, and grain-supported. The characteristic sedimentary structures are cross-bedding (planar and trough), and herring-bone structures. Facies A was deposited in a tide-dominated shallow marine shelf (upper shoreface) environment, as indicated by the cross-bedding and herring-bone cross-stratification [8].

The carbonaceous mudstone facies (Facies B) is brown to dark gray, massive, and characterized by mud cracks and carbonaceous material. Scattered clasts of amber (up to $3 \mathrm{~cm}$ in diameter) were observed. Fossil leaves and carbonaceous plant remains were found in the basal parts of these beds. Based on the sedimentary characteristics of this facies, it was likely deposited in a lagoon environment characterized by low-energy conditions [6].

The laminated shale facies (Facies $\mathrm{C}$ ) is generally light gray to dark brown, thinly-laminated to thin-bedded, and fissile, and contains minor silty shale. Gypsum flakes are commonly intercalated within the laminated shale. This facies gradually grades into the thin-bedded sandstone facies designated Facies $\mathrm{D}$ in the upper part, which is characterized by intercalated sandstone and shale. 


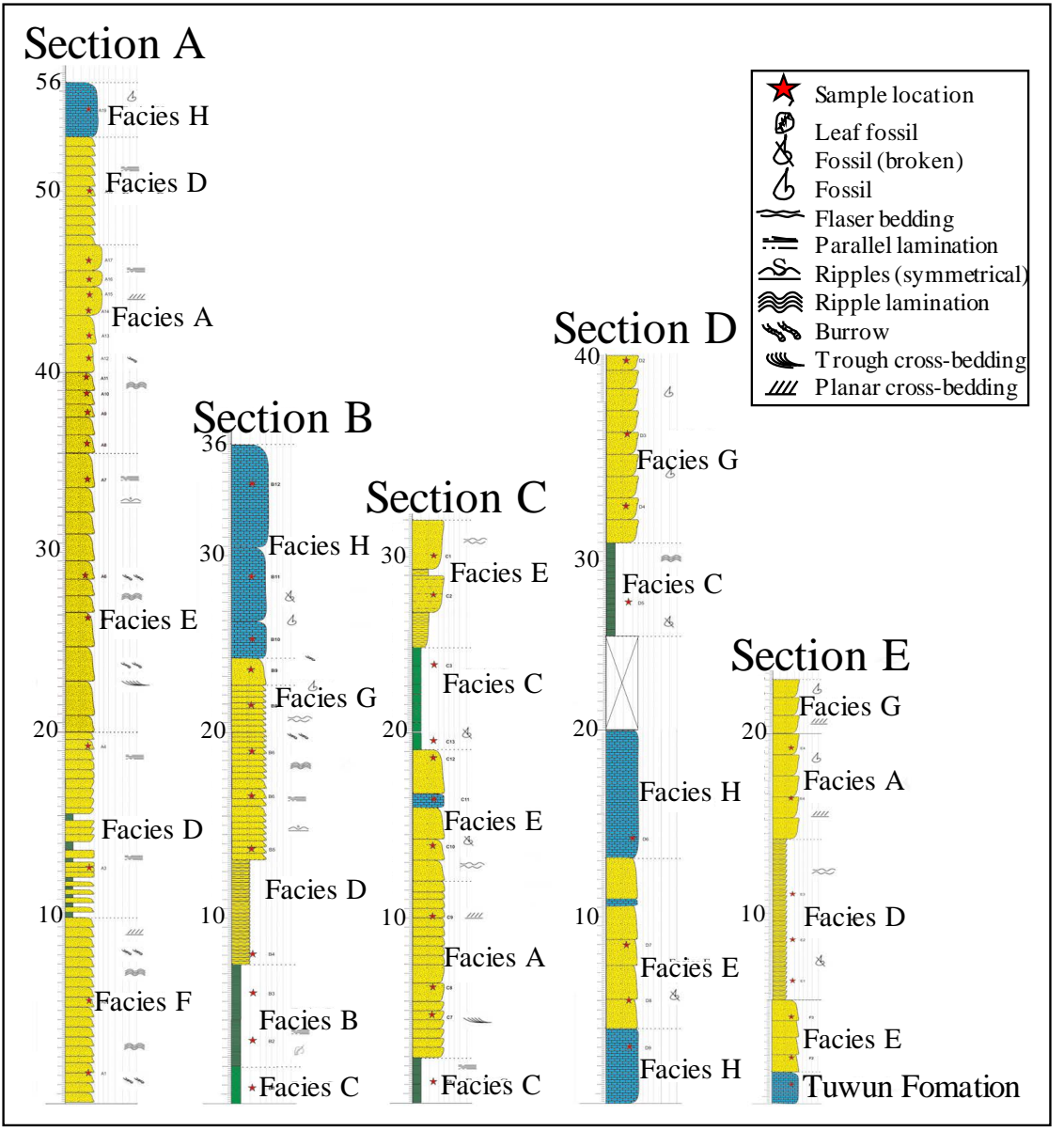

Figure 8. Lithofacies log of five measured stratigraphic sections (Section A, B, C, D and E).

Commonly observed sedimentary structures in this facies are parallel lamination and sandstone lenses. The very fine to fine grain sizes and the thin lamination indicate that this facies was deposited in a shallow marine shelf (lower shoreface) environment [6].

The thin-bedded sandstone facies (Facies D) is dominated by intercalated sandstone and shale. In outcrop, these sandstones are yellow and brownish color, very fine-to fine-grained, and thin- to medium-bedded. Sandstones of this facies are moderately-sorted to very well-sorted and grain-supported, with angular grains. The characteristic sedimentary structures are lenticular bedding, current ripple marks, parallel lamination, wavy lamination and burrow structures. These sandstones are classified as sub-lithic arenite and sub-felds pathicarenite. The sedimentary structures within this facies, such as current ripple marks, parallel lamination, and thin bedding, indicate that this facies was deposited in a shallow marine shelf (lower shoreface) environment [6].

The massive sandstone facies (Facies E) is dominated by sandstone. In outcrop, these sandstones are ash white to yellow in color and very fine- to medium-grained. They are moderately- to well-sorted, and are matrix-supported, with angular grains. The characteristic sedimentary structures are flaser bedding 
and convolute lamination. These sandstones are classified as sub-lithic greywacke. Based on the sedimentary structures and characteristics of this facies, it was likely deposited in a tide-influenced shelf (upper shoreface) environment [6].

The bioturbated sandstone facies (Facies F) is also dominated by sandstone. In outcrop, these sandstones are yellowish to reddish in color, fine-grained, and grain-supported. The grains are moderately- to well-sorted and angular. The most characteristic feature of this facies is the presence of burrow structures. The ichnotaxon Ophiomorpha is common and typically filled with sedimentary iron oxides. This facies is intensely bioturbated. Based on the petrographic analysis, these sandstones have been identified as sub-feldspathic arenite. According to the characteristic vertical burrow structures, it can be inferred that this facies was deposited in a beach (foreshore) environment [6].

The fossiliferous sandstone facies (Facies $G$ ) is dominated by sandstone. In outcrop, sandstones of this facies are yellowish to reddish brown and finegrained. They are moderately to well-sorted and grain-supported with angular grains, and contain abundant fossils and fossil fragments of bivalves, gastropods, bryozoans and foraminifera Based on petrographic analysis, this sandstone is defined as sub-lithic arenite. The characteristics of the sandstone and the abundant fossil content imply that this facies was likely deposited in a coastal (foreshore) environment [6].

This limestone is characterized by bioclasts of an assemblage of large foraminifera dominated by Cycloclypeus sp., Lepidocyclina sp., Miogypsinoides sp., Discocyclina sp., and Planorbulinella sp. Based on the occurrences of larger foraminifers' assemblage, the age of the Ngrayong Formation is assigned as Middle Miocene (Figure 9).
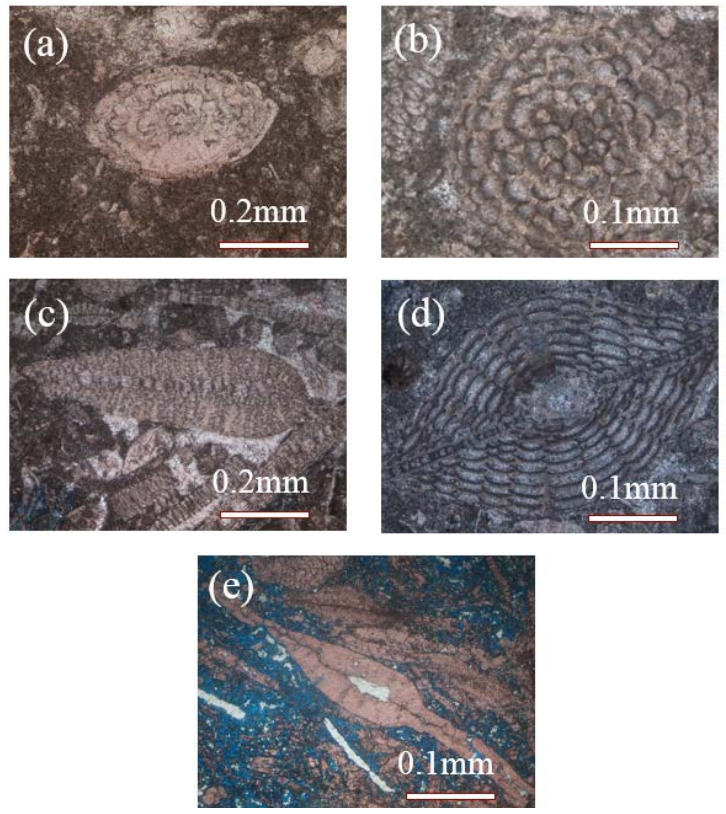

Figure 9. Photomicrographs of foraminiferal assemblages from limestone of facies (Facies H) (a) Discocyclina sp., (b) Planorbulinella sp., (c) Miogypsinoides sp., (d) Lepidocyclina sp. and (e) Cycloclypeus sp. 
In most sections, both the upper and lower contacts of this facies with rocks of other sedimentary facies are sharp. Based on petrographic analysis, these carbonate rocks are matrix-supported and consist of coarse silt to medium-grained sand that is angular to poorly-rounded and poorly-sorted. In composition, the matrix is $5 \%$ quartz, $40 \%-60 \%$ foraminiferal tests, $20 \%-35 \%$ micrite, and $10 \%$ sparry calcite cement. These limestones are therefore classified as packstone and wackestone. Based on the paleontological evidence, especially the presence of Cycloclypeus sp., which is an excellent indicator of paleo-water depth, this facies was deposited in a shallow marine (middle neritic) environment [9].

\section{Reservoir Characteristics of the Ngrayong Sandstone}

Nine outcrop samples of the Ngrayong Sandstone were selected and analyzed to determine their porosity and permeability. Source rock and cap rock were also found in mudstone in our target field, but our research target is reservoir rock (sandstone) and we don't discuss them in this paper. Based on these analyses, the porosities of these sandstones range from $25.97 \%$ to $40.21 \%$, whereas their permeabilities range from 94.6 to 3385 millidarcies $(\mathrm{mD})$. Four samples, namely samples A5, C9, D3, and E7 (Table 2), have permeabilities in excess of $1000 \mathrm{mD}$, whereas the permeabilities of the other five samples (A2, B6, C2, D8, and E6) range from 94.6 to $330.5 \mathrm{mD}$ (Table 2).

Sandstones and limestones in the Rembang area can be categorized into eight lithofacies that exhibit different sedimentological, petrological and petrophysical characteristics. Of the eight lithofacies observed in the Ngrayong Formation, five principal facies are identified as potential reservoir facies: the cross-bedded sandstone facies (Facies A), the thin-bedded sandstone facies (Facies D), the massive sandstone facies (Facies E), the bioturbated sandstone facies (Facies F), and the fossiliferous sandstone facies (Facies $\mathrm{G}$ ).

The cross-bedded sandstones (Facies A) have porosities that range from 34.5\% to $36.4 \%$ and permeabilities from 2836 to $3385 \mathrm{mD}$. These sandstones are very fine- to medium-grained, moderately to verywell-sorted, and grain-supported with angular to sub-rounded grains. These sandstones possess excellent reservoir qualities. The highest permeability, $3385 \mathrm{mD}$, was recognized from a sample from this facies.

The thin-bedded sandstones (Facies D) have porosities of $30.54 \%-30.7 \%$ and permeabilities of $330-274 \mathrm{mD}$. These sandstones generally consist of fine- to very fine-grained sub-angular, moderately and very-well sorted sand grains, and are grain-supported. These sandstones exhibit good reservoir qualities.

The massive sandstones (Facies E) have porosities of $25.97 \%-40.21 \%$ and permeabilities of 113 - $2562 \mathrm{mD}$. These sandstones are matrix-supported with very fine- to medium-grained, moderately to well-sorted sand grains, and are characterized by good to excellent reservoir characteristics.

The measured porosity and permeability of the bioturbated sandstones (Facies F) are $30.3 \%$ and $237.9 \mathrm{mD}$, respectively. These sandstones are fine-grained, moderately to well-sorted, and grain-supported. 
The fossiliferous sandstones (Facies $G$ ) have porosity of approximately $35.2 \%$ and permeability of $2104 \mathrm{mD}$, and are fine-grained, moderately to well-sorted, and grain-supported. Sandstones of this facies are considered to have excellent reservoir qualities.

The greater porosities of the sandstones of certain facies are likely the result their clean nature (i.e., matrix-poor and loosely-cemented). The high porosities and permeabilities of certain samples were also likely enhanced by extensive weathering of the exposed outcrops from which they were collected. This weathering would lead to secondary porosity associated with dissolution of the clay particles and/or matrix in the sandstone.

\section{Conclusions}

Based on data from field investigations and petrographic, mineralogical, sedimentological and paleontological analyses, the characteristics of the Ngrayong Sandstone in the Rembang area can be summarized and interpreted as follows.

These sandstones are generally either grain- or matrix-supported, and are composed of very fine- to medium-grained, angular to poorly-rounded, moderately to very well-sorted sand grains. These sandstones are predominantly classified as sub-felds pathic and sub-lithic arenites, are clean in nature (matrix/ cement-poor), and show some degree of textural maturity; therefore, these rocks may serve as a good reservoir for hydrocarbon accumulation.

Eight lithofacies were identified from five measured stratigraphic sections: cross-bedded sandstone (Facies A), carbonaceous mudstone (Facies B), laminated shale (Facies $\mathrm{C}$ ), thin-bedded sandstone (Facies D), massive sandstone (Facies E), bioturbated sandstone (Facies F), fossiliferous sandstone (Facies G), and bioclastic limestone (Facies $\mathrm{H}$ ). In general, the sedimentary successions of the measured stratigraphic sections are dominated by shallow marine shelf (tidedominated) sandstone facies (Facies A and E), which are overlain by a shallow marine (middle inner neritic) limestone facies (Facies $\mathrm{H}$ ).

The Ngrayong sequence in the Rembang area shows a single transgressiveregressive cycle. Of the eight lithofacies observed in the Ngrayong Formation, five principal facies have been identified as potential reservoir facies: the crossbedded sandstone facies (Facies A), the thin-bedded sandstone facies (Facies D), the massive sandstone facies (Facies E), the bioturbated sandstone facies (Facies F), and the fossiliferous sandstone facies (Facies G). The cross-bedded sandstone facies (Facies A) and the massive sandstone facies (Facies E) were identified as good potential reservoirs rocks based on their characteristics in outcrop, their lateral and vertical distributions, and their sedimentological characteristics.

\section{Acknowledgements}

This research was financially supported by the ASEAN University Network/ Southeast Asia Engineering Education Development Network AUN/SEED-Net and the Japan International Cooperation Agency (JICA). Special thanks are given to Shandy Nandya for help and support during field investigations. 


\section{References}

[1] Mohaghegh, S., Arefi, R., Ameri, S., Aminiand, K., and Nutter, R. (1996) Petroleum Reservoir Characterization with the Aid of Artificial Neural Networks. Journal of Petroleum Science and Engineering, 16, 263-274. https://doi.org/10.1016/S0920-4105(96)00028-9

[2] Ardhana, W. (1993) A Depositional Model for the Early Middle Miocene Ngrayong Formation and Implications for Exploration in the East Java Basin. Proceedings, Indonesian Petroleum Association, Twenty Second Annual Convention, Jakarta, 12-14 October 1993, 395-441.

[3] Pettijohn, F.J., Potter, P.E., and Siever, R. (1987) Sand and Sandstone. 2nd Edition, Springer-Verlag, New York, 553 p. https://doi.org/10.1007/978-1-4612-1066-5

[4] Pettijohn, F.J. (1975) Sedimentary Rock. Halper and R Brother, New York.

[5] Koesoemadinata, R.P. (1980) Geologi minyak dan gas bumi. ITB, Bandung, 296 p.

[6] Nichols, G.J. (2009) Sedimentology and Stratigraphy. 2nd Edition, Blackwell Scientific Publications, Oxford, 419 p.

[7] Kadar, D., and Sudijono. (1993) Systematic Geological Map, Indonesia, Quadrangle Rembang 1509-1 and 6 Scale 1:100.000: Geological Research and Development Centre: 1 Sheet.

[8] Allen, J.R.L. (1982) Sedimentary Structures: Their Character and Physical Basis. Vol. 1. Developments in Sedimentology. Elsevier, Amsterdam.

[9] Pringgoprawiro, H. and Baharuddin. (1979) Biostratigrafi Foraminifera Planktonic dan Bidang-Bidang Pengenal Kaenozoikum-Akhirdari Sumur-Sumur Tobo, Cepu, Jawa Timur. Proceedings PIT VIII Ikatan Ahli Geologi Indonesia, Jakarta, 11-12 December 1979, 21-31.

Submit or recommend next manuscript to SCIRP and we will provide best service for you:

Accepting pre-submission inquiries through Email, Facebook, LinkedIn, Twitter, etc. A wide selection of journals (inclusive of 9 subjects, more than 200 journals)

Providing 24-hour high-quality service

User-friendly online submission system

Fair and swift peer-review system

Efficient typesetting and proofreading procedure

Display of the result of downloads and visits, as well as the number of cited articles

Maximum dissemination of your research work

Submit your manuscript at: http://papersubmission.scirp.org/

Or contact ojg@scirp.org 